\title{
The Analysis of the Conversion of New and Old Kinetic Energy in Third-tier Cities from the Perspective of New Taxes: Taking City A as an Example
}

\author{
Qiaowan Wang \\ Tsinghua University
}

Ao Niu

Renmin University of China

\author{
Guangwei Li \\ National University of Defense Technology
}

The economic adjustment function of taxation has played an important role in promoting the China's conversion of new and old kinetic energy of enterprises. This study based on precious first-hand quarterly data of more than a hundred key tax source companies in City A from 2015 to the first quarter of 2018. The results show that government tax incentives and strengthened supervision have significantly promote the innovation level of enterprises; after the "replacing the business tax with a value-added tax", high labor costs of modern service hinder the speed of new and old kinetic energy conversion.

Keywords: conversion of new and old kinetic energy, tax incentives, human capital cost

\section{INTRODUCTION}

Promoting the conversion of new and old kinetic energy in the economy is an important measure to implement the concept of new development and the supply-side structural reforms in the situation of new development in China. (Wang, 2019) The new kinetic energy implies "4 News", which are new technology, new industry, new format and new mode, to achieve the aim of reducing capacity, inventory, leverage and costs. (Hong, 2016) Shandong is the first pilot province in China for the transformation of new and old kinetic energy. Previous studies build R\&D performance criteria to assess the effects of the reform. For example, Xu et al. (2019) have been assessed the effects of transformation of new and old kinetic energy policy on R\&D development of Shandong province, by constructing 4 prospective of innovation criteria. The results show that the top3 cities of Shandong province get higher marks than other cities in Shandong. Zhang et al. (2019) conduct survey to investigate the effects of the reform on small and medium size intelligence manufacture companies in Shandong, and find that the use of intelligence technologies increases among these companies in the recent years. Li (2019) studies the effects of "4 News" conversion of new and old kinetic energy reform on A City's local marine industry. Previous studies also focus on the influence of the high quality personnel on facilitating the "4 News" conversion (Chen \& Shen, 2019; Zhang, 2019) 
To investigate the real effect of the new kinetic energy transformation, we got valuable first-hand key tax data of A City from State Administration of Taxation of Shandong Province, China, from 2015 to the first quarter of 2018. We focus on how the tax policies affect the research and development of new technology, and how the industry of modern service adapts to "replacing the business tax with valueadded tax reform". By using multi-stage panel data to build multivariate regression models, we analyses the effects and consequences of policies on the change of third-tier cities, with lower GDP comparing with big cities in China, and provides several policy recommendations for local governments.

\section{TAX INCENTIVES TO PROMOTE THE TRANSFORMATION OF INNOVATION}

\section{Tax Incentives Promote the Transformation of Corporate Innovation}

Among the more than one hundred key tax source companies in City A, the level of investment in R \& D from 2016 to 2017 increased significantly, by 70.4\% and 14.7\% respectively. From the perspective of tax incentives, the tax incentives of more than $100 \mathrm{key}$ tax source companies increased significantly in 2016-2017, with year-on-year growth of 10\% and 64\% respectively. We built multi-variant regression models based on the company's quarterly data from 2015 to the first quarter of 2018 in City A to test the impact of VAT and corporate income tax incentives and tax burdens (all divided by sales revenue) on whether to conduct R \& D, and the level of R \& D. In Table 1, Note that "Whether or not to conduct R \& D" is measured as 1 if enterprises conduct R \& D, or 0 otherwise; (2) R \& D level: the ratio of R \& D expenditure to operating income; (3) ***, **, and * mean it is significant at the level of $1 \%, 5 \%$ and $10 \%$ respectively. The regression results of model (1) show that when the value-added tax burden is reduced by 1 percentage point, the willingness of enterprises to research and development increases by 0.647 percentage points, and the t-test value is 2.001 , which is significant. The model (4) shows that if the corporate income tax preference increased by 1 percentage point, and the R \& D level increased by $1.6 \%$ (correlation coefficient 0.087 / R \& D level average 5.289). The t-test value is 16.722 , which is significant at a high level. We control the characteristics of industries and companies in the robustness test models (2), (3), (5), and (6), and the conclusions remain the same. 
TABLE 1

IMPACT OF TAX INCENTIVES ON CORPORATE R\&D

\begin{tabular}{|c|c|c|c|c|c|c|}
\hline \multirow{2}{*}{ Variables } & \multicolumn{3}{|c|}{ Whether or not to conduct R \& D } & \multicolumn{3}{|c|}{ The level of R \& D } \\
\hline & Model (1) & Model (2) & Model (3) & Model (4) & Model (5) & Model (6) \\
\hline \multirow[t]{2}{*}{$\begin{array}{c}\text { VAT } \\
\text { incentives }\end{array}$} & 0.095 & 0.019 & 0.083 & $-0.002 * *$ & $-0.002 *$ & $-0.002 * *$ \\
\hline & $(0.632)$ & $(0.125)$ & $(0.542)$ & $(-1.982)$ & $(-1.650)$ & $(-1.973)$ \\
\hline \multirow[t]{2}{*}{ VAT burden } & $-0.647 * *$ & $-0.608^{*}$ & $-0.754 * *$ & -0.001 & -0.001 & -0.001 \\
\hline & $(-2.001)$ & $(-1.889)$ & $(-2.305)$ & $(-0.251)$ & $(-0.326)$ & $(-0.230)$ \\
\hline \multirow[t]{2}{*}{$\begin{array}{l}\text { Corporate } \\
\text { income tax } \\
\text { incentives }\end{array}$} & $10.180 * * *$ & $10.165 * * *$ & $10.141 * * *$ & $0.087 * * *$ & $0.087 * * *$ & $0.086^{* * *}$ \\
\hline & $(14.826)$ & $(14.870)$ & $(14.785)$ & $(16.722)$ & $(16.763)$ & $(16.611)$ \\
\hline \multirow[t]{2}{*}{$\begin{array}{l}\text { Corporate } \\
\text { income tax } \\
\text { burden }\end{array}$} & -0.105 & -0.103 & -0.110 & 0.000 & 0.000 & 0.000 \\
\hline & $(-1.299)$ & $(-1.280)$ & $(-1.355)$ & $(0.574)$ & $(0.558)$ & $(0.530)$ \\
\hline \multirow[t]{2}{*}{$\begin{array}{c}\text { Return on } \\
\text { Assets }\end{array}$} & & & 0.030 & & & 0.000 \\
\hline & & & $(0.853)$ & & & $(0.077)$ \\
\hline \multirow[t]{2}{*}{$\begin{array}{l}\text { Financial } \\
\text { leverage }\end{array}$} & & & -0.016 & & & -0.001 \\
\hline & & & $(-1.379)$ & & & $(-0.327)$ \\
\hline \multirow[t]{2}{*}{$\begin{array}{l}\text { Investment in } \\
\text { fixed assets }\end{array}$} & & & 0.005 & & & -0.003 \\
\hline & & & $(0.183)$ & & & $(-0.729)$ \\
\hline \multirow[t]{2}{*}{ Industry } & & $0.001 * * *$ & & & $-0.000 * * *$ & \\
\hline & & $(4.068)$ & & & $(-2.597)$ & \\
\hline \multirow[t]{2}{*}{ Constant } & $0.209 * * *$ & $0.149 * * *$ & $0.221 * * *$ & $0.001 * * *$ & $0.001 * * *$ & $0.001 * * *$ \\
\hline & $(13.792)$ & $(7.087)$ & $(12.681)$ & $(4.597)$ & $(5.112)$ & $(4.545)$ \\
\hline Observations & 1,740 & 1,740 & 1,727 & 1,729 & 1,729 & 1,724 \\
\hline Adjusted $\mathrm{R}^{2}$ & 0.112 & 0.120 & 0.115 & 0.140 & 0.143 & 0.140 \\
\hline
\end{tabular}

Taking the transformation of the innovation of the five major industrial clusters in City A as an example, the levels of investment in innovation of the three major industries-aluminum, chemical and grain-have increased year by year. Among them, the key tax source enterprises of City A's leading aluminum industry have started conducting innovative research and development since 2017, with R \& D investment of 2.918 million and sales growth of 1.39 times. The chemical industry started conducting innovation and transformation in 2016. In 2017, the investment in research and development was 81.455 million, 2.3 times which in 16 years, and it is obviously in the trend of upward. The industry of grain has the highest value of R \& D investment. In 2017, R \& D investment was 210 million, a year-on-year increase of $14.3 \%$. As shown in Table 2, from the perspective of tax incentives (tax incentives divided by sales income), the quarterly averages of grain, aluminum, and chemical ranked the top three, 0.087, 0.082, and 0.079 , respectively. In terms of the level of $\mathrm{R} \& \mathrm{D}$ (the amount of $\mathrm{R} \& \mathrm{D}$ expenditure divided by sales income), the quarterly averages of the three major industries are also among the top three, and the rankings remain the same. Therefore, tax incentives have played an important role in promoting the conversion of old and new kinetic energy in the five major industries. 
TABLE 2

COMPARISON OF QUARTERLY AVERAGES OF TAX INCENTIVES AND R\&D LEVELS OF THE FIVE MAJOR INDUSTRIES IN 2015-2018

\begin{tabular}{|c|c|c|}
\hline $\begin{array}{r}\text { Tax incentives and } \\
\text { R \& D expenditures }\end{array}$ & The level of tax preference & $\begin{array}{c}\text { The level of R \& D } \\
\text { expenditure }\end{array}$ \\
\hline Five major industries & 0.082 & 1.403 \\
\hline Aluminum industry & 0.079 & 66.914 \\
\hline Chemical industry & 0.067 & 0.000 \\
\hline Textile industry & 0.002 & 0.000 \\
\hline Aquaculture & 0.087 & 490.501 \\
\hline Grain industry & & \\
\hline
\end{tabular}

Tax Advantages of Strategic Emerging Enterprises are Prominent

The enterprises which have high R \& D investment, low production capital investment, and nonlabor-intensive are defined as strategic emerging enterprises. Strategic emerging enterprises are those that enjoy environmental protection and energy saving, high-tech and R \& D tax incentives. In Table 3 shows the results of t-test subsamples. Note that $* * *, * * *$ indicate significant at $1 \%, 5 \%$ and $10 \%$ levels, respectively. It demonstrates that among the more than one hundred key tax source enterprises in City A in 2015-2018, the investment in fixed assets of strategic emerging enterprises is significantly lower than the quarterly average of non-strategic emerging enterprises by 8 percentage points. The quarterly average of non-strategic emerging enterprises is 1 percentage point lower; R \& D investment is also significantly higher than that of non-strategic emerging enterprises. Strategic emerging enterprises are the main force to promote the economic development of City A, and their R \& D level is outstanding. From 2015 to 2017, the average annual R \& D investment of strategic emerging enterprises in City A was 3.204 million yuan, which was significantly higher than the annual average of 93,100 yuan for non-strategic R \& D enterprises. Compared with the quarterly trend of total tax burden, strategic emerging enterprises have reduced their tax burden by 19.4\% year-on-year in 2017, and non-strategic emerging enterprises have decreased by $2.3 \%$ year-on-year, and their tax advantages have gradually become prominent. Among the city's strategic new enterprises, the higher level of R \& D is the grain industry and the aluminum industry. Among them, starch and starch product manufacturing, edible vegetable oil processing, and ferroalloy smelting accounted for the top three of the total R \& D investment, accounting for $28 \%, 26.2 \%$, and $20.8 \%$ of the total R \& D investment, respectively, and the preferential tax levels also ranked first, fourth, and fifth.

TABLE 3

COMPARISON OF INPUT OF RESOURCES BETWEEN STRATEGIC EMERGING AND NONSTRATEGIC EMERGING ENTERPRISES

\begin{tabular}{|c|c|c|c|c|c|}
\hline & \multicolumn{2}{|c|}{$\begin{array}{c}\text { non-strategic emerging } \\
\text { enterprises }\end{array}$} & strategic emerging enterprises & $\mathrm{t}$ test \\
\hline Variables & Observations & Mean (1) & Observations & Mean (2) & $(1)-(2)$ \\
\hline $\begin{array}{c}\text { Investment in fixed } \\
\text { assets }\end{array}$ & 1768 & 0.320 & 283 & 0.262 & $0.058^{* * *}$ \\
\hline Investment in R \& D & 1768 & 0.000 & 283 & 0.004 & $-0.004 * * *$ \\
\hline $\begin{array}{c}\text { Investment in human } \\
\text { resources }\end{array}$ & 1768 & 0.085 & 283 & 0.078 & 0.007 \\
\hline
\end{tabular}


FIGURE 1

\section{COMPARISON OF TAX BURDEN BETWEEN STRATEGIC EMERGING ENTERPRISES AND} NON-STRATEGIC EMERGING ENTERPRISES

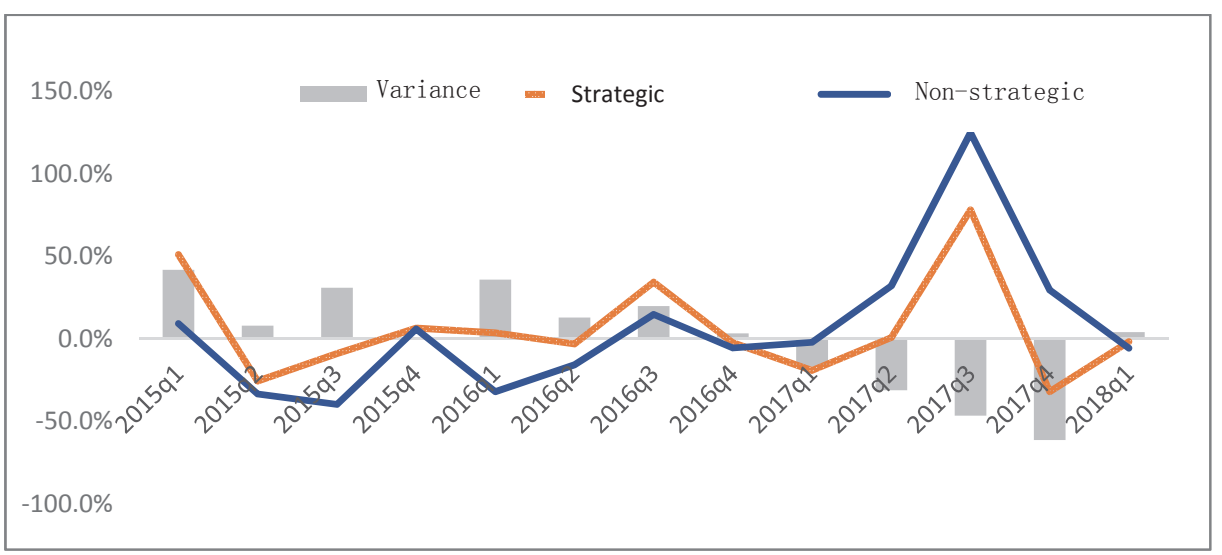

\section{THE INTENSITY OF TAX SUPERVISION ENCOURAGES THE TRANSFORMATION OF INNOVATION}

Strengthening tax collection and management is a powerful guarantee for realizing fiscal revenue. The stronger the tax collection and management is, the lower the possibility of corporate tax evasion and tax avoidance will be, which will contribute to improve the compliance of taxation. Paying taxes in accordance with the law, and reasonable tax planning is the guarantee for enterprises to maximize their economic benefits, and it also induce enterprises to enjoy more tax dividends through transformation of innovation and $\mathrm{R} \& \mathrm{D}$, thereby reducing corporate tax burdens. The survey builds a model of least squares regression based on R \& D expenditure and tax data of the province's different cities in 2015. Data are drawn from the Statistical Yearbook of Shandong Province 2016. The intensity of tax collection and management is measured by the difference between the budget tax and the actual tax. Figure 2 depicts that greater the difference, the higher the intensity of tax supervision. The results of regression show that the stronger the of tax supervision intensity, the higher the R \& D expenditure of enterprises; manifested as that for every 1 percentage point increase in tax collection and management intensity, the R \& D expenditure of enterprises increases by 2.5 percentage points (the ratio of the correlation coefficient to the average level of $\mathrm{R} \& \mathrm{D}=2.1914$ / 86.95). It indicates that tax collection and management does not have a restraining effect on the $\mathrm{R} \& \mathrm{D}$ of enterprises, but instead stimulates the investment in R \& D. 
FIGURE 2

\section{IMPACT OF TAX SUPERVISION INTENSITY ON R\&D (UNIT: 100 MILLION YUAN)}

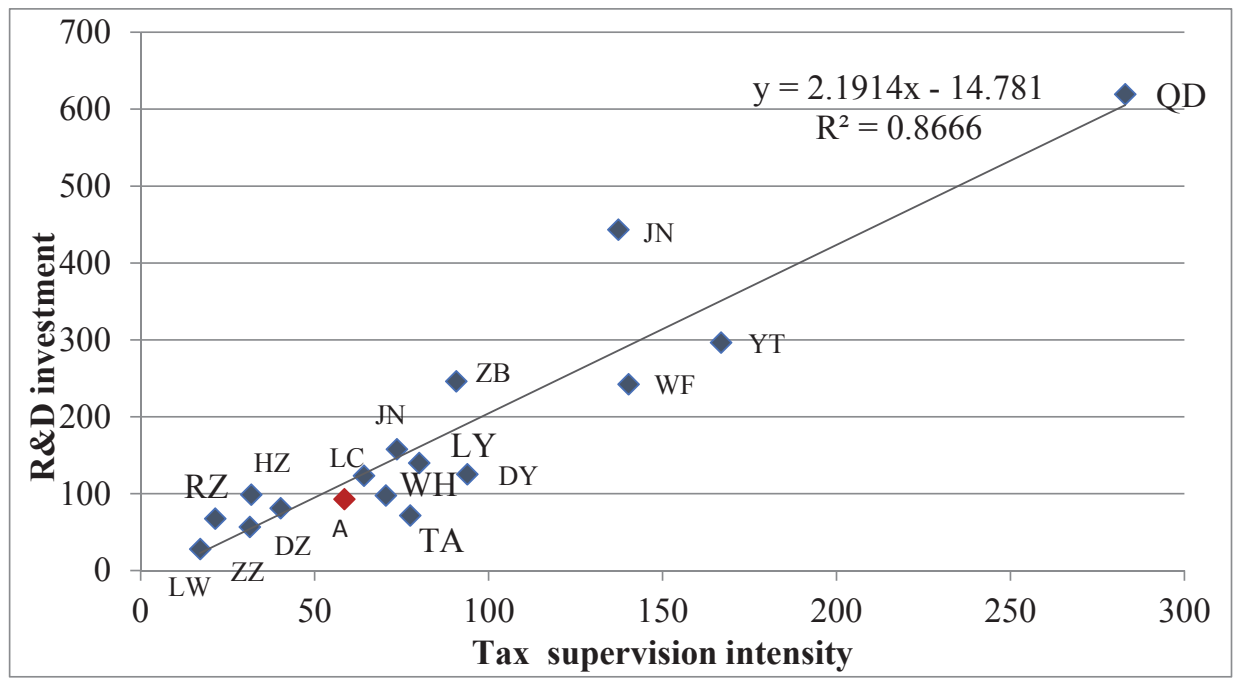

\section{MODERN SERVICE INDUSTRY IS FACING NEW CHALLENGES OF TAXATION}

\section{Modern Service Industry is Developing Rapidly}

The traditional service industry of City A is dominated by wholesale and retail, which accounted for $52.8 \%$ and $47.2 \%$ of the traditional service industry by 2018 , respectively. The proportion of traditional service industry and modern service industry has developed rapidly from 90:10 in 2015 to 42:58 so far. According to the [2012] No. 70 document of the Ministry of Science and Technology, the modern service industry is represented by financial insurance, information software, leasing and business services, scientific research technology, culture, and real estate. Based on the classification, as shown in Figure 3, in 2016, the operating profit of modern service industry increased slightly by $2.3 \%$ year-on-year, and it increased by $195 \%$ year-on-year in 2017 , which is 2.3 times the growth rate of profits in the traditional service industry over the same period, accounting for $56.12 \%$ of the total revenue of the service industry. The modern service industry has made outstanding contributions to the improvement of the output value of the service industry in City A. The number of modern service industry enterprises has increased year by year, from 1 financial company in 2015 to 17 in 2018, including multi-format modern service enterprises such as logistics, information, real estate, finance, and leasing. Among them, the finance, real estate and logistics industries have developed rapidly since 2017 , accounting for $50 \%, 18 \%$ and $19 \%$ of the modern service industry in 2018. 
FIGURE 3

PROPORTION OF MODERN SERVICE INDUSTRY IN CITY A IN 2018

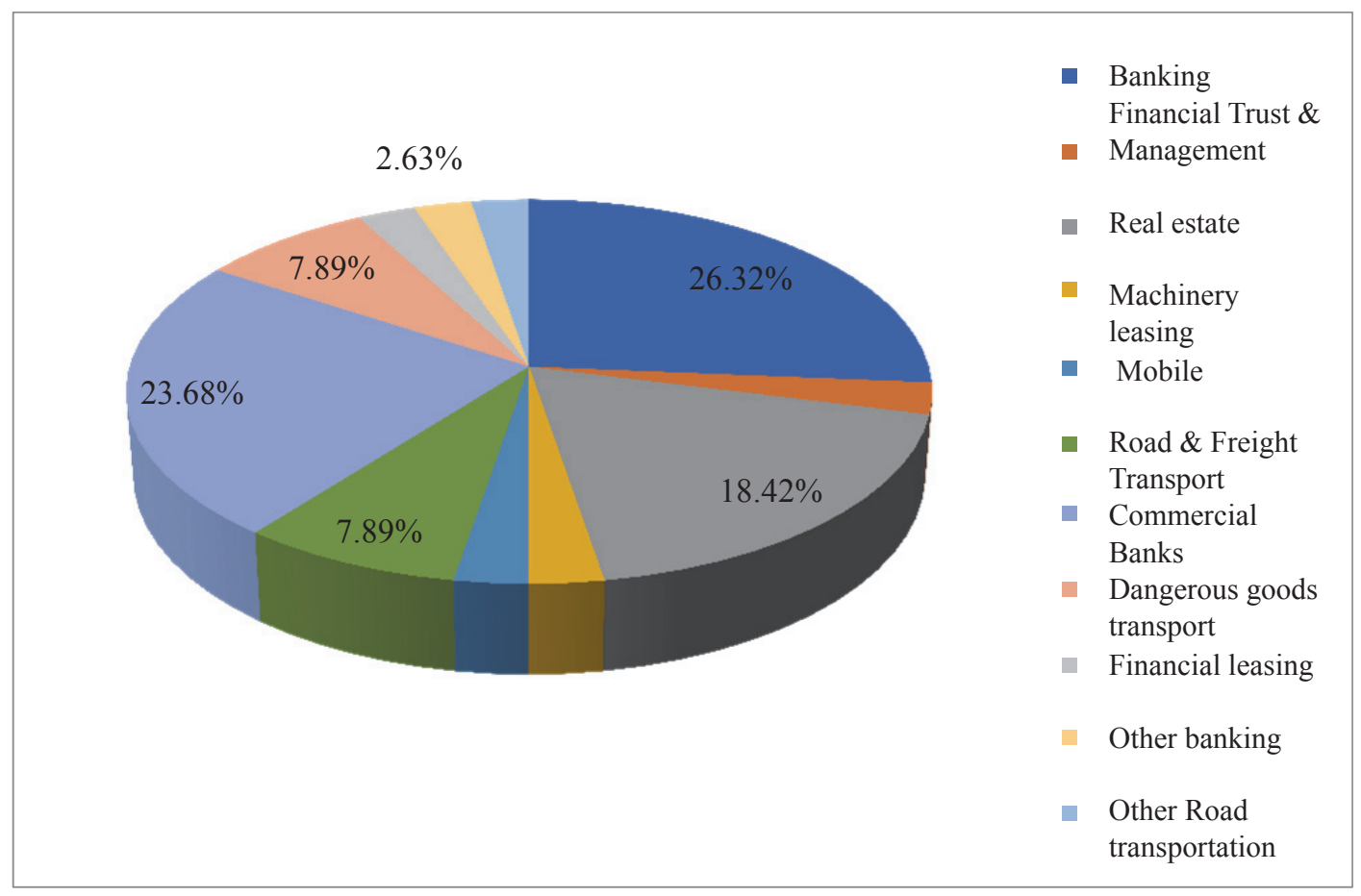

\section{The Labor Costs is Huge in Modern Service Industry}

In 2015-2017, VAT credits of traditional and modern service industry in City A are increasing year by year. Among them, the traditional service industry increased from 12.93 million yuan in 2015 to 88.57 million yuan in 2017, and the value of VAT slightly by 270,000 yuan from 2015 , and the VAT burden reduced by 1 percentage point. The VAT deduction for modern services has increased significantly from 280,000 yuan in 2015 to 3.72 million yuan in 2017 , but the VAT burden has increased by 2 percentage points. From 2016 to 2017, the sales revenue of the modern service industry declined slightly, from RMB $313,933,600$ to RMB 31,316,800, but profits fell from RMB 11,428,900 to RMB 4,284,444, which was a serious contraction. From the perspective of human resource costs, human costs increased by $50 \%$ and 20\% respectively in 2016 and 2017 (2015: 0.109; 2016: 0.166; 2017: 0.205). Table 4 shows the comparison of the tax burden and labor cost between traditional service industry and modern service industry. It reveals that the labor cost, value added tax and corporate income tax burden of modern service industry is higher than that of traditional service industry, $t$-test is significant at 0.05 and 0.01 levels, respectively. Table 5 shows the tax burden and labor costs of various industries in modern services. It reveals that the development and management of real estate has the highest labor costs among modern service industries, whose value-added tax burden is heavier compared with other modern service industries; the second highest are the logistics industry, road transport of dangerous goods and other road cargo transports, all of which have large labor costs and high VAT burdens. The top three corporate income tax burdens are road transport of dangerous goods, mobile telecommunications services and currency banking services (industry tax burdens are: $0.255 ; 0.182 ; 0.154$ ), and labor costs in these three industries are also high $(0.176 ; 0.079 ; 0.110)$. 
TABLE 4

COMPARISON OF TAX BURDEN AND LABOR COST BETWEEN TRADITIONAL SERVICE INDUSTRY AND MODERN SERVICE INDUSTRY

\begin{tabular}{|c|c|c|c|c|c|}
\hline & \multicolumn{2}{|c|}{ Traditional service industry } & \multicolumn{2}{c|}{ Modern service industry } & T-test \\
\hline Variables & Observations & Mean (1) & Observations & Mean $(2)$ & $(1)-(2)$ \\
\hline Labor costs & 153 & 0.059 & 92 & 0.181 & $-0.122^{* *}$ \\
\hline VAT incentives & 153 & 0.094 & 92 & 0.009 & $0.085^{* * *}$ \\
\hline VAT burden & 153 & 0.011 & 92 & 0.032 & $-0.021^{* * *}$ \\
\hline $\begin{array}{c}\text { Corporate income tax } \\
\text { incentives }\end{array}$ & 153 & 0.000 & 92 & 0.000 & 0.000 \\
\hline $\begin{array}{c}\text { Corporate income tax } \\
\text { burden }\end{array}$ & 153 & 0.029 & 92 & 0.065 & $-0.035^{* *}$ \\
\hline
\end{tabular}

TABLE 5

QUARTERLY AVERAGE OF TAX BURDEN AND LABOR COST OF MODERN SERVICE INDUSTRY IN 2015-2018

\begin{tabular}{|c|c|c|c|c|c|}
\hline $\begin{array}{l}\text { Modern service } \\
\text { industry }\end{array}$ & $\begin{array}{l}\text { VAT } \\
\text { incentives }\end{array}$ & $\begin{array}{l}\text { VAT } \\
\text { burden }\end{array}$ & $\begin{array}{l}\text { Corporate income } \\
\text { tax incentives }\end{array}$ & $\begin{array}{l}\text { Corporate income } \\
\text { tax burden }\end{array}$ & $\begin{array}{l}\text { Labor } \\
\text { costs }\end{array}$ \\
\hline $\begin{array}{l}\text { Mobile telecommunications } \\
\text { services }\end{array}$ & 0.000 & 0.000 & 0.000 & 0.000 & 0.019 \\
\hline Financial leasing services & 0.000 & 0.000 & 0.000 & 0.000 & 0.000 \\
\hline $\begin{array}{c}\text { Mobile telecommunications } \\
\text { services }\end{array}$ & 0.000 & 0.008 & 0.000 & 0.182 & 0.079 \\
\hline Road cargo transportation & 0.049 & 0.012 & 0.000 & 0.084 & 0.142 \\
\hline Money banking services & 0.001 & 0.014 & 0.000 & 0.154 & 0.110 \\
\hline $\begin{array}{l}\text { Financial trust and } \\
\text { management services }\end{array}$ & 0.000 & 0.020 & 0.000 & 0.000 & 0.197 \\
\hline $\begin{array}{l}\text { Road transport of dangerous } \\
\text { goods }\end{array}$ & 0.084 & 0.037 & 0.000 & 0.255 & 0.176 \\
\hline $\begin{array}{l}\text { Other road cargo } \\
\text { transportation }\end{array}$ & 0.001 & 0.048 & 0.000 & 0.000 & 0.086 \\
\hline $\begin{array}{c}\text { Real estate development and } \\
\text { management }\end{array}$ & 0.001 & 0.059 & 0.000 & 0.015 & 0.464 \\
\hline $\begin{array}{c}\text { Other machinery and } \\
\text { equipment rental }\end{array}$ & 0.000 & 0.073 & 0.000 & 0.000 & 0.000 \\
\hline
\end{tabular}

The Tax Reduction Effect of "Replacing the Business Tax with A Value-added Tax" is Significant, and the Cost of Human Capital Leads to an Increase in Tax Burden

The overall value-added tax burden of the service industry after City A 's "replacing the business tax with a value-added tax" increased by $35 \%$ and $10 \%$ in 2016 and 2017, respectively. The regression model in Table 6 reveals that the "replacing the business tax with a value-added tax" in the traditional service industry reduces the VAT burden, and the correlation coefficient is negative. However, the tax burden of modern service industry increased after the "replacing the business tax with a value-added tax" (the value of $t$ was 2.066, a significant level of 0.05). Among them, the increase in VAT on the currency banking industry got the rapidest increase, and the VAT burden for 2016 and 2017 increased by 1.2 and 34.8\%, respectively. From the model (1), it can be concluded that the tax burden of the currency banking industry 
has increased significantly at the level of 0.05 after the "replacing the business tax with a value-added tax ". After the "replacing the business tax with a value-added tax ", modern service industries and currency banks that are mainly human capital may not be able to deduct labor costs, which may lead to an increase in tax burden.

\section{TABLE 6 \\ IMPACT OF "REPLACING THE BUSINESS TAX WITH A VALUE ADDED TAX" ON VAT BURDEN}

\begin{tabular}{|c|c|c|c|}
\hline \multirow{2}{*}{$\begin{array}{l}\text { VAT burden } \\
\text { Tax policy }\end{array}$} & Money banking & Traditional service industry & Modern service industry \\
\hline & Model (1) & Model (2) & Model（3） \\
\hline \multirow[t]{2}{*}{ The policy of tax reform } & $7.907 * *$ & -2.542 & $5.193 * *$ \\
\hline & $(2.280)$ & $(-0.316)$ & $(2.066)$ \\
\hline \multirow[t]{2}{*}{ Constant term } & -0.000 & $2.504 * * *$ & 0.000 \\
\hline & $(-0.000)$ & $(3.880)$ & $(0.000)$ \\
\hline Adjusted $\mathrm{R}^{2}$ & 0.123 & -0.007 & 0.045 \\
\hline
\end{tabular}

\section{POLICY RECOMMENDATIONS}

\section{Encourage the Transformation of Innovation Strategy of Enterprises and Enjoy Tax Incentives}

Tax incentives play an important regulatory role in improving the return on investment of enterprises, enhancing their market competitiveness, and strengthening their transformation from old kinetic energy to new one. Corporate income tax has provided many preferential tax policies for high-tech R \& D enterprises and energy-saving and environmentally-friendly enterprises, and it contribute significantly to the promotion of corporate R \& D. Enterprises should respond to market competition in a timely manner, complete the conversion of old and new kinetic energy, and enjoy more tax incentives.

High-tech enterprises cannot do without the capital injection of venture capital enterprises in upstream industry, from Ministry of Finance [2018] No. 55, the new tax policy effective from July this year further supports venture capital enterprises and angel investment individuals, and introduces a series of new deduction policies. This will lead a new wave of enthusiasm for start-up technology enterprises and venture capital enterprises, injecting fresh blood into the conversion of old and new kinetic energy. The venture capital enterprises in City A have not yet formed a scale, it should be advocated that enterprises grasp tax dividends in a timely manner through tax preferential policies, and solidify the core competitiveness led by new technologies.

\section{Strengthening Tax Collection and Supervision to Stimulate the Transformation of Corporate Innovation Strategy}

Strengthening tax collection and management is a powerful guarantee for realizing fiscal revenue. The stronger the tax collection and management, the lower the possibility of corporate tax evasion and tax avoidance, which will help improve tax compliance. Paying taxes in accordance with the law and reasonable tax planning is the guarantee for enterprises to maximize economic benefits, which also forces enterprises to enjoy more tax dividends through the transformation of innovation and R \& D. It not only improves the competitiveness of the industry, but also reduces corporate tax burden.

\section{Responding to the Policy of "Replacing the Business Tax with a Value-added Tax" Actively, and Improve the Mechanism of Introduction and Incentive of Talents}

The policy of "replacing the business tax with a value-added tax" has avoided repeated taxation in the past, reduced corporate tax burden, and promoted corporate transformation. It is an important measure for China's supply-side reform. The high tax burden of City A's real estate development and management and currency banking services industry also reflects the situation of the two hot industries after the tax reform. 
In addition to opening new business models and striving for deductions, it cannot be ignored that the cost of human resources is too high and cannot be deducted. The most important thing in modern service industry is human capital, and there should be perfect mechanism of introduction and incentive of talents. To advance to a high level of the modern service industry, it is necessary to strengthen the capabilities of scientific and technological innovation, improve the competitiveness of local service companies, and it is inseparable from the introduction and cultivation of professional talents. It is necessary to establish a perfect mechanism of talent introduction and incentive to realize the transformation of the old and new models of the service industry. In this way, it will not only help the modern service industry to optimize the allocation of human capital, reduce labor costs, but also play an important role in achieving high returns for the modern service industry.

\section{REFERENCES}

Chen, C., \& Shen, W. (2019). The innovation of training mode of craftsmen in higher vocational education based on the transformation of New and Old Kinetic Energy. Chinese and Foreign Entrepreneurs, 34, 112-113.

Hong, Y. X. (2016). Accurately understanding the objectives and tasks of supply side structural reform. China's Industrial Economy, 6, 14-21.

Li, L. (2019). A study on the development of beach economic industry under the transformation of New and Old Kinetic Energy. Modern Commercial Industry, 40, 13-14.

Wang, L.Y. (2019). Driving forces of scientific and technological innovation for ideas and measures for the transformation of New and Old Kinetic Energy conversion. Technology Wind, 32, 6.

Xu, Z. W., Fan, Y. M., Pan, J. S., Yao, S. L., \& Zhang, W. (2019). Research on innovation ability of New and Old Kinetic Energy Conversion core cities in Shandong Province. Modern Industrial Economy and Information, 9, 13-16.

Zhang, D. H. (2019). The transformation of New and Old Kinetic Energy should occupy the talent highland. People's Forum, 31, 76-77.

Zhang, H. R., Fan, Z. Y., Wei, P., Cheng, W. Q., \& Chen, H. (2019). Study on the transformation of New and Old Kinetic Energy if Shandong Province. Science and Technology Economic Guide, 23, 184-185. 